\title{
情報セキュリティに関する取り組みについて の最新動向"
}

\section{武田 圭史 $* 1$ • Nicolas CHRISTIN *1*2 • Davar PISHVA*1}

\section{概要}

これまで情報セキュリティの分野は, 暗号学と混同 されることが多く，特に暗号は軍事的応用に関連して 発展してきた歴史的経緯や高度な数学を必要とするこ とから，一般に知られることは少なかった。結果とし て，つい最近まで一般の人々が情報セキュリティに関 する十分な知識や意識を持つ機会は少なかった。しか しながら昨今ではこの状況は大きく異なってきてい る. 誰もが, インターネットへ接続するだけで, 脅威 やその対策についての理解の有無にかかわらず様々な セキュリティリスクに直面するようになっている。そ の結果, セキュリティ工学(Security Engineering)と 呼ばれる分野は, 純粋な技術分野から人間的要素そし て政策などを総合的に考慮しなければならない分野に 変化している。この論文では, 利便性を備えたセキュ リティ, ピアツーピアネットワークのセキュリティ, 情報家電のセキュリティなどの分野における研究の概 要を説明し, 進化するセキュリティ工学の実践的な研 究事例を紹介する。特に安全なシステムデザインの過 程において人間の振る舞いなどを考慮することがどの ように技術的な解決策に制約を与えるかなど，技術以 外の要素を考慮することの重要性について述べる.

\section{1 . はじめに}

ここの10年の間に情報セキュリティ研究は大きく変 化している.かつては数学のエリートが政府または軍 の機関の下で研究を行っているというイメージが強 かったが, 最近では情報セキュリティは非常に学際的 な領域であると認識されるに至っている。この背景に ある主な要因はセキュリティの脅威の本質にあると考 えられる。

通信ネットワークの急激な普及, オンライントラン

\footnotetext{
$\dagger$ Recent Trends in Information Security Challenges Keiji TAKEDA, Nicolas CHRISTIN and Davar PISHVA

*1 カーネギーメロン大学日本校

Carnegie Mellon CyLab Japan

*2 カーネギーメロン大学情報ネットワーク研究所

INI/CyLab, Carnegie Mellon University
}

ザクションの増加及びコンピュータシステムの小型化 は情報セキュリティの分野を大きく二つの方法で変化 させた。まず第一に, 我々が日常生活の中で直面する 情報セキュリティのリスクが過去に比べて高いものと なっている，例えばアイデンティティ盗難 (identity theft)などは，かつてはそれほど見かけることのない マイナーだった問題だが, 現在に打いては多くの人に とって無視することのできない大きな問題となってい る. 第二に攻撃を受ける可能性のある対象の数や種類 が大きく増加していることがあげられる．今日ネット ワークに接続するあらゆるコンピュータ機器がリスク にさらされて扣り，携帯電話からインターネットに接 続されたコンピュータまで, ほとんどすべての人が攻 撃対象となる何らかの機器を保有している。これら多 くの潜在的攻撃対象のユーザは直面している脅威や可 能な防御策について限られた理解しかしていない.こ のような状況がセキュリティ技術者の取り組みを困難 なものにしている.

本稿では, 情報セキュリティ技術者がいかに学際的 な領域で問題に取り組んでいるかを紹介することに よって, 情報セキュリティという分野が人間科学 (例：心理学等), 技術そして政策の相互作用に関わる 問題であることを述べる.

以下，第 2 章では心理学とセキュリティの融合領域 において我々が行っている研究事例の概要を示す。第 3 章ではネットワーク・セキュリティのピアッーピ アネットワークに関する取り組みを説明する。第 4 章 では情報家電におけるセキュリティのあり方を通じ て, 再度情報セキュリティとユビキタスコンピュー ティングの「使いやすさ」の位置づけについて考える. 最後に第 5 章においてこれらの結論を述べる.

\section{2．使いやすいセキュリティ}

「安全なユーザ認証」ほど情報セキュリティにおける ヒューマンファクターの重要性を示す事例はないだろ う。フィッシング[2]やスパイウェア[3]そしてオンラ インでのアイデンティティ盗難 (identity theft)といっ た脅威の出現は，システムセキュリティと“心理的な 
受容性” [6]との関係を示している。あるシステムが 安全な部品を使って構築されたとしても利用時におけ るヒューマンエラーへの対応ができていなければ安全 とは言えない，例えば，コンピュータ上でのユーザ認 証を行う場合に，暗号を適切に利用しているので安全 であると考えられているかもしれない。しかし，もし ユーザがパスワードを紙に書いてコンピュータに貼つ ていたとしたら，そのシステムのセキュリティは極端 に弱いということになってしまう。

特に携帯電話のようなポータブルデバイスに関して はユーザの振る舞いを充分考慮しする必要がある。携 帯電話は単なる通信デバイスよりもずっと多くの機能 を提供するようになって打り，鉄道の電子チケット (例：日本に打けるSuica, Icoca, PiTaPa 等), デ ビットカード(例：香港におけるオクトパスカード), 音楽やビデオのダウンロードなど直接料金請求を伴う オンラインサービスなどがあげられる，さらに，携帯 電話はシステムやセキュリティといったものについて ほとんど知識や経験のない広い範囲の人々に利用され ている。

現在利用されている大半の携帯電話の認証スキーム はユーザが知っている何かを認証のトークンとして提 示することでユーザ自身を認証する知識ベースのアプ ローチである．知識ベースのような認証方式を選択し 利用する理由は他の方法(例：スマートカード, バイ オメトリクス認証)が考えられているほど安全ではな いからである。人々は深く考えることなく携帯電話機 のロックを解除するためのスマートカードを携帯電話 機の近くに置き, 結果として盗難に対して無防備に なってしうだろう。いくつかの携帯電話 (例 : DoCoMo 902iS シリーズなど)にはバイオメトリクス 認証が搭載されるようになっているが，製造コストの 増加に対する効果が上がっているとは言い難い. 主要 な課題の一つはバイオメトリクスが，対象となるバイ オメトリクスの模造(例：。携帯電話に付着する指紋か ら作成された“グミ指”[5])をコストをかけずに見分 けることが困難なためである

残念なことに，パスワードベースの認証はさらに 問題を抱えている。 小さなキーパッドからテキストを 入力することは容易ではなく，携帯電話に打いては， 何度かの誤りを入力した場合に電話を利用不可能にす るようなロック機構を用いた上で, 暗証番号 (PIN)の ような短いパスワードに頼らざるを得ない。携帯電話 がロックされた場合の不便さや販売店でロックを解除 してもらう手間を避けるためユーザはパスワードや暗 証番号として覚えやすいものを選択するようになって しまう。誕生日のような覚えやすい暗証番号やパス
ワードは, ソーシャルエンジニアリングを使った攻撃 などに対し極端に弱いものとなる $[4]$.

簡単に言えば知識べースの認証スキームは

a) 非常に使いやすいが非常に脆弱

(例：ユーザは任意に選択した暗証番号を使用)

b) 攻撃に対して強いが使いにくい

(例：ユーザはランダムな暗証番号を使用)

のどちらかである。我々の使いやすいセキュリ ティの研究は使いやすさとセキュリティを再構築する ことで知識べースの認証スキームに打ける新しいデザ インを提供することである.

\section{1 提案のアプローチ}

心理学分野に打ける研究[7]では画像はテキストと 比べ大変記憶しやすいことが分かっている．グラフィ カル・パスワードのような画像べースの認証スキーム はテキストのパスワードによる認証に対するより安全 な代替手段として考えられる。しかしながらCranor とGarfinkel [1] が概要をしめしている従来のグラフィ カルパスワードのスキームでは, 非常に限定された適 用しか行われていない。画像べースの認証スキームを 適用するにあたっての主な障害はその適切な実装が困 難であるところにある。実際現存するグラフィカルパ スワードについては以下にあげる問題がある.

・正当なユーザに対する無視できない䛊認識率 ・正当なユーザに成りすまそうとする不正なユーザに 対する無視できない誤認識率

したがって我々は従来のグラフィカルパスワードで 利用された認知プロセスから前進する必要がある。 我々が適用する認知プロセスは, 人間の自身が選択し た画像に関してその低品質化 (degraded)された画像 を認識する能力である。

人は見る画像から主要な特徴を抽出する能力を持っ ており，画像がかなり低品質化されたとしてもその特 徴を容易に抽出することが可能である。その一方で, 元画像をみていない場合には心理的に低品質化された 画像から元の画像を再構築することは困難である。例 として図 1 をとりあげる。両方の画像を見た場合に図 1 (b)は図1 (a)が加工されたバージョンであることは 明らかであるが，図1（a）を見ることなくして図1（b） から図 1 (a)を推測することは困難である.

我々の認証の問題を当てはめると, 画像のセットを 選択した正当なユーザは, 低品質化された画像セット のなかから自分が選択した画像の低品質化されたバー ジョンを選択することは難しくないはずである。しか 


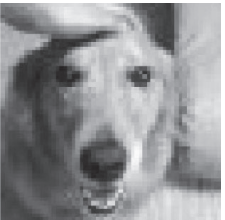

（a）オリジナル画像

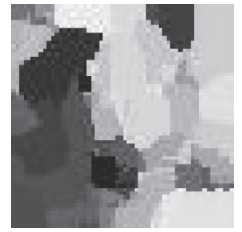

（b）加工された画像
図 1 オリジナルと加工された画像の関係の例

し，他人になりすましシステムに対して不正なアクセ スを試みようとするものに対しては，低品質化された 画像しか見ることができないので元画像が持つヒント を得ることができない

例えば正当なユーザは犬を飼っていてレースカーの 愛好者だと想定する。例えばソーシャルエンジニアリ ングによってその知識を持つ攻撃者は, 犬とレース カーに関するチャレンジ画像セットが認証の組み合わ せるかもしれないと考える。そして，この情報はシス テムのセキュリティを突破するために利用することが できる。一方，もしチャレンジ画像のセットが全て低 品質化された画像のみ(ユーザによって選択されたも の及びダミ一)が提示された場合には，正当なユーザ に対しては犬や車を識別するために十分な情報を提供 しながら，同じ画像は攻撃者にとってはランダムかつ カラフルなシミとしか見えない.

\section{2 実装と結果}

Hayashiらは提案するグラフィカル認証スキームを Nokia N70携帯電話上に実装した[8]。実装の目的は 二つあった。第一に，我々のスキームが非常に限られ たディスプレイのサイズ, キーパッドといくらかの ファンクションキーという最小限のキーボードという 一般的な携帯電話の物理的制約条件下でも使いやすい ことを示す。第二に適用している新たな認知プロセス の有効性を評価するというものであった．

この実装ではユーザは 27 個の画像によるチャレンジ セットから 3 つ画像を正しく選択することで認証を 受けることとした(ユーザポートフォリオ)。ユーザは 電話機がロックされるまでに 3 回の認証の試みを行う ことが許可される。画像が選択される順序については 認証プロセスとしては考慮されないものとした。

チャレンジセットの画像は 9 個の画像からなる $3 つ$ の異なるスクリーンに表示される。提示された 1 つの スクリーンにはユーザのポートフォリオから $0,1,2$ または全ての画像が表示されることになる。罒2 2 ここ れら 3 つのスリーンを示したものである. 各画像に 対するキーバインドは携帯電話のキーに対応してお
り, ナビゲーションは携帯電話のファンクションキー を通じて行われる。ショルダーハッキング(哯き込み) を避けるために, フィードバックは全ての画像の選択 が終わるまで表示されない。 つまり，画面にはどの画 像が選択されたか決して表示されないこととなる.

実験では54名の参加者を 3 つのグループに分け使い やすさに関するテストを実施した．数分間のトレーニ ングフェーズを実施した後, 最初のグループの全ての 参加者は, 加工された画像を使って認証を行うことが できた。加工された画像であっても記憶に残りやす く, 2 日後, 1 週間後および 4 週間後に施したテスト においてもグループの全ユーザが認証を行うことに成 功した。 これらのユーザは記憶しやすいがソーシャル エンジニアリング攻撃に対して脆弱な加工していない 画像を使ったグループと同じ(完全な)成功率で認証を 行うことができた。 3 目のグループはランダムな画 像(ソーシャルエンジニアリング攻撃に対して有効だ が記憶しにくい)を使用したが, 特に一定時間経過後 において認証を成功させるには困難を伴った。例えば 第 3 グループの $89 \%$ のユーザが 1 ケ月後に認証を成功 させることができなかった。

「使いやすさ」に関するテストの結果は, 提案するス キームは, 加工をしない画像を使った場合と同等の使 いやすさを持つことを示した。ささらに同時に，なりす ましをしようとする攻撃者にとっては, どの画像が ユーザの選択によるものかを推測するのが困難にな り，安全性が高まったといえる。

まとめると, 加工された画像をグラフィカルユーザ 認証に使用することは使いやすさとセキュリティを両 立する上で非常に有効な手法であることが言える。

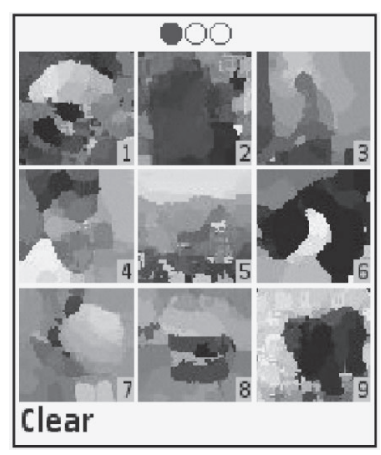

図 2 チャレンジセットの例

完全なチャレンジセットはユーザが自由にナビ ゲート可能な同様の 3 つのスクリーンにより構成 される。 


\section{3 . ピアッーピアネットワークのセキュリ ティ}

1990年代後半に出現したNapster [9] に代表される ピアッーピア $(\mathrm{P} 2 \mathrm{P})$ ネットワークのうち, 特にファイ ル交換・共有を目的としたソフトウェアは, インター ネット上での音楽や映画などの不正な著作物の交換な どに使用されることが多い。日本においては，近年の ブロードバンドや常時接続環境の普及に伴い, ピア ツーピアネットワークの利用が広まった。しかし，著 作権法違反による取り締まりの限界や，ピアッーピ ア・ファイル共有ネットワーク上にコンピュータ内の 情報を漏洩させるコンピュータウィルスの出現により 被害が続出し, 社会問題となっている.

ピアツーピアファイル共有ネットワークにおける情 報セキュリティについて 2 つ大きな課題がある。一 つ目は著作物の違法に交換・共有行為であり，本来の 著作権者が十分実効性のある対応をとることが困難な 点である。二つ目は特に日本で発生した多くの情報漏 洩事故において，一旦漏洩した情報の拡散を止めるこ とができず漏洩した情報はいつでも誰でもダウンロー ドできる状態になってしまうことである。このため個 人情報などが漏洩した場合などは被害の回復が困難で ある。ここでは情報セキュリティの観点からこれらの 課題に対する取り組みについて記述する。

\section{1 ピアツーピアネットワークにおける著作権管理}

ピアツーピアファイル共有ネットワークを利用する ことで，音楽や映画などの他人の著作物を含むデータ を違法に公開することが, 重大な罪の意識を持つこと なく行われている。著作権者の立場からは，これらデ ジタルコンテンツに対して本来得るべき対価を失うこ とになり，その被害金額は単一のソフトウェアだけを 見ても100億円にも上ると言われている $[10]$. ネット ワーク上で流通される著作物を管理するための技術を "network-DRM (Digital Right Management)"と呼 び，その目的はデジタルコンテンツのコピーを作成で きなくするようなものではなく，デジタルコンテンツ のピアッーピアネットワーク上などでの拡散を防止す ることである．基本的な考え方としては，大量の無用 なファイルや検索情報をネットワークに配布し, ネッ トワークユーザが該当するコンテンツを発見すること を困難にするというものである．

ここでは上記のような特定ファイルを発見しにくく するために偽のデータ/情報を拡散させる行為のこと をポイゾニングと呼んでいる．ピアツーピアソフト ウェアなどでのポイゾニングについては, 米国の娛楽
産業によって実際に実施されている。

LiangらはFastTrack (KaZaA) 上での情報拡散の様 子などについて最初の分析を行った[11].これに続き Christinらはさまざまなピアッーピアネットワークに 対して計測を行いポイゾニングが著作権侵害等の事例 への対策として有効であることを示した [12] [13]. 最近の研究 $[14]$ では, 人間によるユーザを対象とした 実験により，ピアツーピアネットワークにおけるポイ ゾニングに対するユーザの行動に関する分析も行われ ている。

ポイゾニングの技術としては, ファイル共有ソフト ウェア上に実際には利用できないダミーファイルを送 出するアイテム・ポイゾニングという方法と，ファイ ル検索等に使用するインデックスに関して虚偽の情報 を作成し，ファイル共有ソフトゥェア上に送出するイ ンデックスポイゾニングという手法が存在する。

\section{2 ピアツーピアネットワークにおける情報漏洩への 対策}

日本に打いては, 特に強い匿名化の機能を備えた Winny[15]などの匿名ファイル共有ソフトが広く利用 されており，他人の著作物を公開したユーザやプログ ラムの開発者が著作権法違反ならびにその幇助で逮捕 されるなどの事件が起こっている。2005年から 2006 年にかけては, Winny上で感染を広げるコンピュータ ウィルスが多数出現し, デスクトップの画像や電子 メール, コンピュータ上に保有されたユーザデータな どの情報をWinnyネットワーク上に流出させるという 事故が多発した。官公庁からも国民の個人情報を含む 多くの重要情報が漏洩し事態を重く見た政府が国民に Winnyの不使用を呼びかけるなど社会問題に発展し た.

著者らは，前項で紹介したポイゾニングという技術 がWinnyネットワーク上でも有効に機能するかを検証 するため以下の実験を行った [16]. 実験にあたって は, まずWinnyプロトコルにより通信を行うことので きる互換プログラムWinny Analyzerを用い, Winny ネットワーク上で流通されるインデックス情報(ある ファイルがどのノードで公開されているかを知らせる キー情報) 収集・分析した。また, ポイゾニング データをWinnyネットワーク上に送出するためのッー ル, Winny Poisoning Toolを用いてアイテムポイゾニ ング及びインデックスポイゾニングの効果を確認し た。

Winny Analyzerによる収集データの分析では， Winnyを運用しているノードの約 $98 \%$ 只本に所属す るI Pアドレスを使用していることや, Winny上で流 
通されるデータの多くが，アニメやポルノ動画などに 関する名称を付けられたものであることなどが確認さ れている。また，コンピュータウィルスによる漏洩 ファイルと思われる名称を持つファイルは共有されて いる全てのファイルのうちの $1 \%$ 程度しかないことが 確認された。

また，十分なサンプル数が得られておらず統計的な 検証は行われていないものの, 企業等の漏洩データの 名称を持つものについては，企業が漏洩事故について 記者発表を行った場合の漏洩データと, 記者発表を 行っていない漏洩事故による漏洩データでは, 記者発 表を行っていないケースの方がデータの拡散が少ない 傾向があることが確認された。

図 3 にアイテムポイゾニングによるダミーファイル の拡散状況を示す。

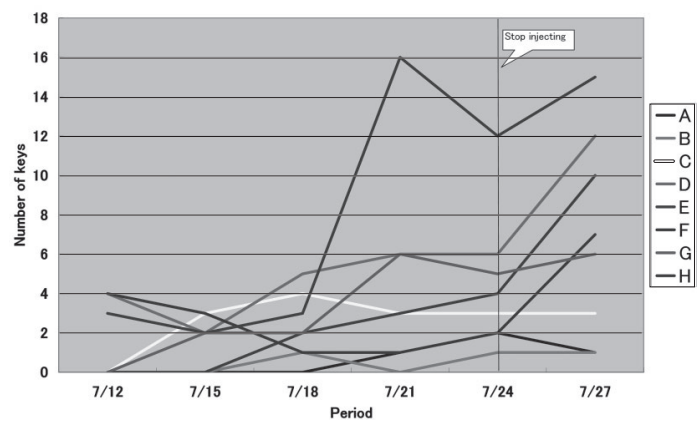

図３アイテムポイゾニングによるダミーファイルの 拡散状況

図 3 のアイテムポイゾニングにおいては, ウィルス による漏洩ファイルと同様に似せたファイル名を持つ ファイルをネットワーク上に公開し，Winnyネット ワーク上に送出したダミーファイルがいくつ存在する かを時系列にプロットすることでポイゾニングファイ ルの分散の過程を追った。観測期間は 7 月 12 日から同 月27日の間であり $\mathrm{A}$ Ｈはそれぞれ異なるファイルの 種類を示している。 7 月24日の時点でファイルの公開 を停止したがその後もファイル数の増加を示している ことからWinnyにおいてアイテムポイゾニングは有効 に機能する可能性が高いことが明らかになった。

一方図 4 は期間 7 月 21 日から同月 27 日の間で虚偽 のインデックス情報を公開し，その虚偽の情報に関す るインデックス情報の広がりを確認したものである. 同様に $\mathrm{A} \sim \mathrm{G}$ はそれぞれ個々のファイルを識別するも のである。

アイテムポイゾニングが一旦他のノードに情報が格 納されればそのノードから新たにインデックス情報が 作成されファイルがダウンロードされる毎に情報が増

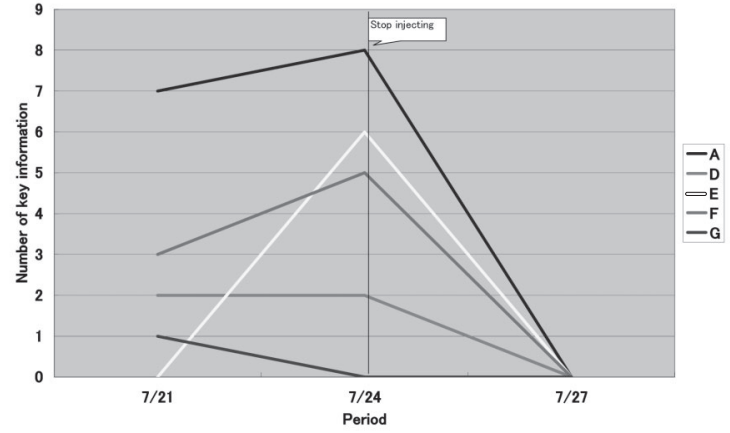

図 4 インデックスポイゾニングによる虚偽インデッ クスの拡散状況

えることになるが, 図 4 に示すインデックスポイゾニ ングにおいては，7月24日にポイゾニングを停止する とただちに虚偽インデックス情報の流通がなくなり， ポイゾニングの効果がなくなることが確認された。し たがってWinnyネットワークに拈いてインデックスポ イゾニングを行うためには永続的に虚偽インデックス を提供し続けるホストを維持する必要があることが明 らかになった。

本実験を通じWinnyのような匿名ピアッーピアファ イル共有ソフトに一旦情報が漏洩すれば，その情報の 拡散を停止することは不可能と言われてきたが，ポイ ゾニングを適切に実施することで，漏洩情報がそう いったものを収集するユーザの手に入りにくくするこ とができ, 被害の軽減に繋がることが確認された。

\section{4 . 情報家電におけるセキュリティ}

現在我々は自動車, 電話, 娛楽や家電などコン ピュータを搭載した様々な技術に取り囲まれて生活を している。様々な電気製品をインターネットに接続し て利用することは技術の進歩に打ける新たな局面をも たらしている。

\section{1 セキュリティの必要性}

情報家電をインターネットに接続することは，悪意 のある攻撃に対して我々を脆弱にする危険性もはらん でいる。侵入者は住所, 購買や飲食の嗜好, ライフス タイルや娛楽，そのようなサービスを受けるために使 用されたクレジットカード番号などといった個人情報 を盗むかもしれない. 情報家電機器が他の攻撃のため の踏み台として使用される可能性もある。

例えば日本においては，デフォルト設定で認証なく アクセス可能なWebプロキシの機能を備えたDVD/ HDDビデオレコーダがスパムメッセージの送信のた めの踏み台として使用されるという事件が発生してい る[17]。他の事件では, 製造工程でコンピュータ 
ウィルスが混入された音楽プレーヤーが出荷され， ユーザのコンピュータに感染を広げる危険性があった ことが確認されている[18]。プライバシー侵害の問題 に関しては，携帯電話で使用されるブラウザが送信す るリファラ(referer) 機能が適切に実装されていな かったために, 新しいWebページにアクセスする毎, (ハイパーリンクのクリックでなく)直接アドレスを指 定した場合でも，直前に閲覧していたぺージの情報が 送信されるという事例が発生している。このブラウザ の欠陥は，直前にアクセスしていたページを送信する ことでユーザの嗜好を第三者に暴露しているととも に, 前のページにアクセスする際必要とされたプライ ベートな情報(ユーザ名, パスワード等を含む)が, 次 に表示したサイトに対して送信される危険性もあった [19]。また, 家庭用ルータの組み込み機器のバッファ オーバフローの脆弱性を攻略し周辺機器への完全なア クセスを取得することに成功したという報告も行われ ている $[20]$.

\section{2 実装上の取り組み}

多種多様な情報家電の普及と新たなネットワーク技 術の開発は, 図 5 に示すと打りユーザ及びサービス提 供者の双方に対して，ホームネットワークのサービス とセキュリティの管理を複雑なものにしている.

これらのデバイスについてセキュリティを実装する ことは, 利用可能なリソース (例：複雑な計算を要す る暗号処理などが困難な限られたCPU能力，長時間 高いピークが必要な計算が制約されるバッテリーによ る給電など。)

さらに，ネットワーク全体のセキュリティ強度はそ の最も脆弱なリンクに依存するため，ネットワーク接 続された情報家電ネットワークのセキュリティ強度 は, 最も脆弱な小規模な情報家電機器によって決定さ れると言える。ささにこの問題を難しくする要素は, 家電機器ユーザは，情報システムに関するスキルを 持った管理者ではなく，むしろ技術に関する知識を持 たないことを前提としなければならないことである。

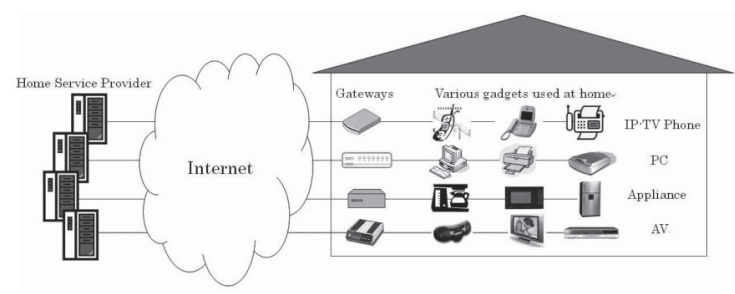

図 5 ヘテロジニアスなホームネットワークと関連す るサービス提供者についての概観

\section{3 セキュリティモデル}

情報家電のセキュリティ要件に対応するためのモデ ルを構築するために，まず最初に情報家電機器を表 1 に示す 8 種の異なる機能区分に分類した，次に，イン ターネットに機器を接続した場合に想定される脅威を 列挙した(表 2 )。さらにその脅威に対抗するために必 要な対策について可能な対抗手段を検討した(表 3 ).

\section{表 1 情報家電機器の機能分類}

\begin{tabular}{|c|c|c|}
\hline No & Function & Example of Product or Usage \\
\hline 1 & $\begin{array}{l}\text { Content } \\
\text { Retrieval }\end{array}$ & $\begin{array}{l}\text { Broadband TV, Microwave Oven, HDD } \\
\text { Recorder (for TV program, etc) }\end{array}$ \\
\hline 2 & $\begin{array}{l}\text { Content } \\
\text { Storage/Usage }\end{array}$ & $\begin{array}{l}\text { HDD Recorder (for TV program, etc), } \\
\text { MP3 Player }\end{array}$ \\
\hline 3 & $\begin{array}{l}\text { Communication } \\
\text { /Messaging }\end{array}$ & $\begin{array}{l}\text { VoIP, IP-TV Phone, All kinds of Emails } \\
\text { System, Healthcare System }\end{array}$ \\
\hline 4 & $\begin{array}{l}\text { Remote } \\
\text { Surveillance }\end{array}$ & $\begin{array}{l}\text { Security Camera, Gas/Fire Sensors, } \\
\text { Refrigerator, Lighting Fixture, Door Lock }\end{array}$ \\
\hline 5 & Remote Control & $\begin{array}{l}\text { Air Conditioner, Lighting Fixture, TV, } \\
\text { TV Program Recording }\end{array}$ \\
\hline 6 & $\begin{array}{l}\text { Remote } \\
\text { Maintenance }\end{array}$ & Firmware Update, Trouble Report \\
\hline 7 & $\begin{array}{l}\text { Instrument } \\
\text { Linkage }\end{array}$ & Networked AV Equipments \\
\hline 8 & $\begin{array}{l}\text { Networked } \\
\text { Game }\end{array}$ & Family Type.g.ame Machine \\
\hline
\end{tabular}

上記においては，情報家電機器に必要となるセキュ リティ対策はそれらの機器が提供する機能により決定 されると考えている，対策を考える上では対象となる 家電機器がスタンドアローンの形態で利用されるの か, 家庭内ネットワーク (FAN： family area network) 環境において相互に接続されて利用されるのかを区別 する必要がある。

我々は，スタンドアローンで利用される機器につい てはオープン・サービス・ゲートウェイ (OSGi)の仕 様に基づき, 中央サーバに格納されたセキュリティ機 能を実行する [21][22]のに対し，ネットワークに接続

表 2 情報家電機器について想定される妿威

\begin{tabular}{|c|c|c|}
\hline No & $\begin{array}{c}\text { Common } \\
\text { Threat } \\
\end{array}$ & Example of an Attack \\
\hline 1 & $\begin{array}{l}\text { User } \\
\text { Impersonation }\end{array}$ & Impersonation using password \\
\hline 2 & $\begin{array}{l}\text { Device } \\
\text { Impersonation }\end{array}$ & $\begin{array}{l}\text { Impersonation of a device using its } \\
\text { faulty certificate }\end{array}$ \\
\hline 3 & $\begin{array}{l}\text { Service } \\
\text { Interruption }\end{array}$ & $\begin{array}{l}\text { Distributed Denial of Service } \\
\text { (DDOS) }\end{array}$ \\
\hline 4 & Data Alteration & $\begin{array}{l}\text { Data alteration of transmitted or } \\
\text { stored data }\end{array}$ \\
\hline 5 & $\begin{array}{l}\text { Worm/Virus } \\
\text { Infection }\end{array}$ & $\begin{array}{l}\text { Infiltration and/or damaging of a } \\
\text { computer system }\end{array}$ \\
\hline 6 & $\begin{array}{l}\text { Phishing } \\
\text { /Pharming }\end{array}$ & Impersonation of users' destination \\
\hline 7 & $\begin{array}{l}\text { Data } \\
\text { Wiretapping }\end{array}$ & $\begin{array}{l}\text { Information leakage through } \\
\text { wiretapping }\end{array}$ \\
\hline 8 & $\begin{array}{l}\text { Firmware } \\
\text { Alteration }\end{array}$ & Replacing of firmware at will \\
\hline 9 & $\begin{array}{l}\text { OS/Software } \\
\text { Vulnerability }\end{array}$ & $\begin{array}{l}\text { Launching of worms and attacks } \\
\text { using such vulnerabilities }\end{array}$ \\
\hline
\end{tabular}


表 3 対策案の概要

\begin{tabular}{|c|c|c|}
\hline No & $\begin{array}{l}\text { Common } \\
\text { Threat }\end{array}$ & Proposed Countermeasure \\
\hline 1 & $\begin{array}{l}\text { User } \\
\text { Impersonation }\end{array}$ & \multirow{2}{*}{$\begin{array}{l}\text { Introduce a certificate mechanism } \\
\text { through memory card like devices. }\end{array}$} \\
\hline 2 & $\begin{array}{l}\text { Device } \\
\text { Impersonation }\end{array}$ & \\
\hline 3 & $\begin{array}{l}\text { Service } \\
\text { Interruption }\end{array}$ & $\begin{array}{l}\text { Control through network and access } \\
\text { mechanism to outside world. }\end{array}$ \\
\hline 4 & Data Alteration & $\begin{array}{l}\text { Introduce access control and } \\
\text { certificate mechanism. }\end{array}$ \\
\hline 5 & $\begin{array}{l}\text { Worm/Virus } \\
\text { Infection }\end{array}$ & $\begin{array}{l}\text { Use virus protection software and } \\
\text { prepare to handle new } \\
\text { vulnerabilities. }\end{array}$ \\
\hline 6 & $\begin{array}{l}\text { Phishing } \\
\text { /Pharming }\end{array}$ & $\begin{array}{l}\text { Consider using } \text { SSL to } \\
\text { assure.g.enuineness of displayed } \\
\text { sites. }\end{array}$ \\
\hline 7 & $\begin{array}{l}\text { Data } \\
\text { Wiretapping }\end{array}$ & $\begin{array}{l}\text { Protect communication via IPSEC, } \\
\text { SSL/TLS. }\end{array}$ \\
\hline 8 & $\begin{array}{l}\text { Firmware } \\
\text { Alteration }\end{array}$ & $\begin{array}{l}\text { Use physical access control for } \\
\text { update procedure. }\end{array}$ \\
\hline 9 & $\begin{array}{l}\text { OS/Software } \\
\text { Vulnerability }\end{array}$ & $\begin{array}{l}\text { Educate R\&D people on security and } \\
\text { conduct product test. }\end{array}$ \\
\hline
\end{tabular}

される家電機器をユニバーサル・ホームサーバと呼ぶ 機器によって管理するモデルを提案している $[21]$.

\section{4 新たなセキュリティ・アーキテクチャ}

スタンドアローンで利用される機器のセキュリティ 要件を満たすことはシンプルではあるが, 実際には多 くの機器が相互に接続された形態で利用されると考え られる。この点を考慮すれば, 前述のセキュリティ要 件及び情報家電機器に関連するセキュリティ上の課題 についての最も効率的な方法は以下のとおりである.

1. ホームゲートウェイを介して信頼に足るネット ワークオペレータがセキュリティ管理の支援サー ビスを提供する

2.インターネットに接続可能な機器の製造業者に対 しそのようなユニバーサルゲートウェイを利用し た遠隔での操作と管理を可能とするドライバやア プリケーションの開発を促す.

本方式の概要を眓 6 に示す. ネットワークオペレー タにより操作されるユニバーサルホームゲートウェイ はネットワーク家電機器への接続点として利用され る. 本アーキテクチャでは情報家電機器に対する全て のトランザクションはローカル, リモートに関わらず 全てこのユニバーサルホームゲートウェイを通じて行 われることを想定している.

ここでは 3 つの基本的な使用シナリオを取り上げ る，1つ目はFANのユーザによるローカルサービス に対するアクセス (例：。他の部屋に設置されたビデオ レコーダに格納された映画の鑑賞), 次にリモート サービスのダウンロード，そして 3 つ目がFAN環境 において相互接続された情報家電機器のリモートユー

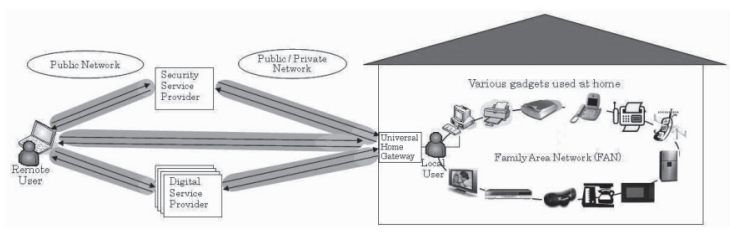

図 6 ネットワークオペレータによる情報家電のセ キュリティ管理

ザによる操作である (例：. 勤務先からの空調の操作な じ).

FAN の内部においてはユーザはパスワードによる ログインを行うことができ, ユニバーサルホームゲー トウエイに格納された各ユーザのアクセス制御情報 (例：.18歳未満に対するアダルトビデオの閲覧禁止, 学校に通う子供達に対する 11 時以降の動画の閲覧禁止 など)に基づきアクセス制御が行われる.

FAN内のリモートサービスサイトヘアクセスする 際にはユニバーサルホームゲートウェイが認証サーバ 機能によって各ユーザを認証しアクセス権限を設定す るとともに, リモートサービスサイトとユーザ間に要 求されたサービスを保護するための安全な通信経路が 設定される。家電機器に対するリモートアクセスはユ ニバーサルホームゲートウェイがリモートユーザのア クセス権限を確認・検証しデータ転送の際の安全な通 信によって実現される。

このアーキテクチャはセキュリティ上の問題につい てはユニバーサルホームゲートウェイを通じてネット ワークオペレータが製品ベースで管理される必要があ る。使用しやすい認証メカニズムは幅広い範囲で受け 入れられるための重要な要素である. 我々は製造業者 やサービスプロバイダに個々の情報家電機器のリソー スの制限を克服しそれらのセキュリティの問題を通常 の一般のユーザが容易に解決できるようにするために 本技術の適用を推薦する. PKIも本アーキテクチャの 重要なセキュリティ・コンポーネントであり，実装や 運用にあたっては製造業者や，ネットワーク運用者， サービス提供者などの協力が必要である。

\section{5. おわりに}

本論文では，利便性を備えたセキュリティ，ピア ツーピアネットワークのセキュリティ, 情報家電のセ キュリティに関する研究を事例としてとりあげ, 安全 なシステムの設計や実装において, 人間の振る舞いや 使いやすさなど技術以外の要素を十分に考慮すること の重要性を示した。

情報セキュリティにおいては守るべき情報資産の重 要度はユーザの振る舞いや認識によって変化し, また 
それらに詨する妿威についても意思を持った人である 場合が多いと思われる。午のため今後情報セキュリ ティ技術がさらに有効な対策とて利用されるために は, 行動科学や社会学, 政治学や法律学など人文社会 系の学問領域と技術の融合領域において研究活動が活 発に展開されることが望まれる。

\section{参 考 文 献}

[1] L. Cranor and S. Garfinkel, editors. Security and Usability: Designing Secure Systems That People Can Use. O’Reilly Media, Sebastopol, CA, 2005.

[ 2 ] R. Dhamija, J. D. Tygar, and M. Hearst. Why phishing works. In Proc. 2006 ACM Conference on Human Factors in Computing Systems (CHI' 06), pages 581-590, Montreal, QC, Canada, April 2006.

[3] N. Good, R. Dhamija, J. Grossklags, D. Thaw, S. Aronowitz, D. Mulligan, and J. Konstan. Stopping spyware at the.g.ate: A user study of notice, privacy and spyware. In Proc. 1st Symposium on Usable Privacy and Security (SOUPS), pages 43-52, Pittsburgh, PA, July 2005.

[ 4 ] D. Klein. "Foiling the cracker": A survey of, and improvements to, password security. In Proceedings of the USENIX Security Workshop, 1990.

[ 5 ] T. Matsumoto, H. Matsumoto, K. Yamada, and S. Hoshino. Impact of artificial gummy fingers on fingerprint systems. In Proceedings of SPIE: Optical Security and Counterfeit Deterrence Techniques IV, 2002, volume 4677, pages 275 - 289, San Jose, CA, January 2002.

[6] J. Saltzer and M. Schroeder. The protection of information in computer systems. Proceedings of the IEEE, $63(9): 1278-1308,1975$.

[ 7] RN Shepard. Recognition memory for words, sentences and pictures. Journal of Verbal Learning and Verbal Behavior, 113(1):95-121, 1967.

[ 8 ] E. Hayashi, N. Christin, R. Dhamija and A. Perrig. For your eyes only: A novel user authentication system for small mobile devices. Working paper. 2007

[ 9 ] C. Bengt and G/ Rune. The Rise and Fall of Napster An Evolutionary Approach. Proceedings of the 6th International Computer Science Conference on Active Media Technology. 2001.

［10］永沢 茂.Winny上の著作権侵害ファイル, 被害額は 100 億円相当〜ACCSとJASRACが試算，インターネッ トウォッチ, December 2006

[11] J. Liang, R. Kumar, Y. Xi, and K. Ross. Pollution in P2P file sharing systems. Proc. IEEE Infocom 2005.

[12] N. Christin, A. Weigend, and J. Chuang. Content avail- ability, pollution and poisoning in file sharing peer-topeer networks. In Proc. 6th ACM conference on Electronic commerce $\left(\mathrm{EC}^{\prime} 05\right)$.

[13] N. Christin. Macrovision interdiction patent applications. May 2005.

part I: http://groups.sims.berkeley.edu/pam-p2p/ index.php? $=108$

part II: http://groups.sims.berkeley.edu/pam-p2p/ index.php? $\mathrm{p}=109$

[14] U. Lee, M. Choi, J. Cho, M. Sanadidi, and M. Gerla. Understanding

Pollution Dynamics in P2P File Sharing. Proc. IPTPS 2006.

[15］金子勇.Winnyの技術, アスキー, 2005.

[16] T. Niiyama, H. Miwa, N. Chrisin and K.TaKeda. Thwarting information security threats in modern anonymous P2P software. Working paper. 2007.

[17］鷹木 創, “東芝, HDD 搭載 DVD レコーダ「RD」シ リーズが “踏み台”になる色険性”, インターネット ウォッチ, October 2004

http://internet.watch.impress.co.jp/cda/news/2004/ 10/06/4882.html.

[18］クリエイティブメディア株式会社, “Creative Zen Neeon デジタルオーディオプレーヤーの問題に関する お客様への報告と対応について”，プレスリリース， September 2004

http://jp.creative.com/corporate/pressroom/releases/welcome.asp?pid=12181.

[19] KDDI, “auからの打知らせ, au携帯電話, TU-KA 携 帯電話に打けるEZWeb ブラウザのホームページ URL の送出について”, KDDI ニュース, December 2005 http://www.au.kddi.com/news/topics/au_topics_ index20051209.html.

[20] Ukai, Yuji. "Exploiting Real-Time OS Based Embedded Systems Using the JTAG Emulator", PACSEC-JP, 2005.

[21] D. Pishva, K. Takeda, "A Product Based Security Model for Smart Home Appliances", 40th Annual IEEE International Carnahan Conferences on Security Technology, pp. 234-242 (2006).

[22] OSGi Alliance http://www.osgi.org.

（2007年 4 月18日 受付）

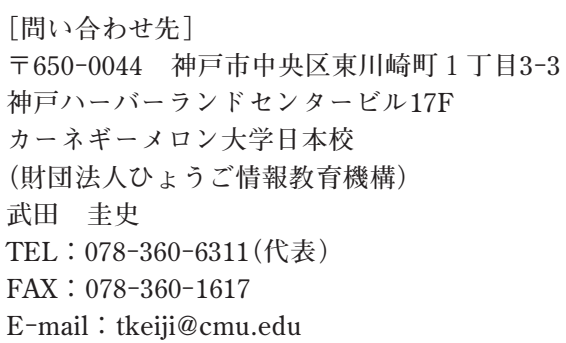


著 者紹 介

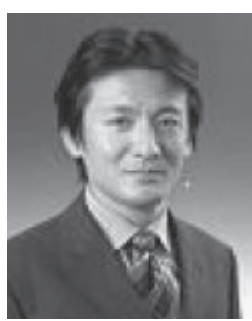

望望苗热定 [非会員]

慶応義塾大学大学院政策・メディア 研究科後期博士課程修了. 防衛庁. 航 空自衛隊, アクセンチュア (株), カー ネギーメロン大学情 報ネットワーク 研究所客員教員を経て, 同大学日本校 教授.この間情報セキュリティ分野に 打ける研究開発・運用・人材育成・ ンサルティング等に従事. 博士（政 策・メディア).

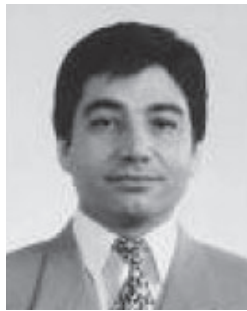

\section{Davar PISHVA [非会員]}

フィリピンのAteneo de Manila Univ. で修士号, 三重大学大学院で情報工学 博士号を取得. 大阪大学工学研究科に 客員講師として来日し, その後, 日本 企業に勤務. 三重大学工学部の非常勤 講師等を経て, CMU日本校教員に就 任. 博士（工学）

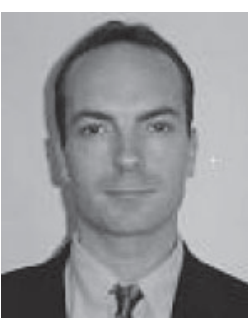

\section{Nicolas CHRISTIN [非会員]}

カーネギーメロン情報ネットワーク 研究所教員, CyLabシステムサイエン ティスト及びカーネギーメロン大学日 本校常駐教員。1999 年フランスの Ecole Centrale Lilleにて工学学士号を 取得後,バージニア州立大学に扎いて コンピュータサイエンス分野の修士号 (2000年) 及び博士号（2003 年）を取 得. 2002 年から 2003 年までノーテル アドバンスドテクノロジーグループに て勤務し, その後 2 年間, カリフォル ニア州立大学バークレイ校の情報管理 およびシステム学部に扔いて博士研究 員として勤務。 